\title{
CULTIVATION TECHNIQUES FOR SIX ALPINE TAXA
}

\author{
Elspeth MaCKintosh
}

Brief descriptions and cultivation techniques are given for six alpine taxa - Androsace tapete Maxim., Daphne cneorum L. var. pygmaea.Stoker, Helichrysum montanum DC., Lilium souliei (Franch.) Sealy, Primula dryadifolia Franch. and Stellera chamaejasme L.

\section{INTRODUCTION}

The current Rock Garden at the Royal Botanic Garden Edinburgh (RBGE) dates from 1907 when the Regius Keeper of the time, Sir Isaac Bayley Balfour, decided to replace the existing, highly compartmentalised rock garden with a more naturalistic design. In 1975 a cedar-framed Alpine House was constructed on the north side of the Garden adjacent to the Palm House. Surrounded by troughs and frames, the Alpine House is dedicated to the cultivation and display of alpines that require dry overwintering conditions. Both the Alpine House and Rock Garden are serviced from the Alpine Yard, a propagation and cultivation area dedicated to alpine plants. In total more than 7,000 accessions representing in excess of 5,000 taxa of alpine plant can be found growing in these three areas. The cultivation knowledge built up by the staff who work in these areas is immense and this paper describes the cultivation of just six diverse species.

\section{Androsace tapete. Primulaceae}

Androsaces have long been among the most favoured cushion plants for alpine growers. Prior to the 20th century the majority in cultivation came from Europe, but with the opening of frontiers in Nepal, the Himalaya in general and later China, many new species have become available in the last 20 to 30 years.

Androsace tapete is one of the Asian introductions. It is a true 'high alpine', assuming the tight cushion form typical of plants from high elevations. The cushion is made up of small tightly-packed leaf-rosettes over a core of withered foliage from previous seasons. The oval-shaped leaves are small (4mm long) and covered with silky hairs which give the leaf-rosette a woolly appearance. In winter the cushions are silvery-grey in colour while in May, in the wild, the whole cushion is white, smothered in flower. The flowers are single and, like many high altitude plants, totally sessile. The corolla is white with a greenish or yellow eye which turns red on 
ageing. After flowering new rosettes grow from the rosette tip and the cushion enlarges gradually.

A. tapete is closely related to $A$. muscoidea which is found in the Indian west Himalaya and in west Nepal. A. tapete has a wider distribution, growing in the drier regions north of the Himalayan range in Nepal, Bhutan, Tibet, and throughout the Sino-Himalaya. It generally grows in loose stony soil on shady banks and amongst scrub at elevations of 3,700-5,500m.

The plants in the collection at RBGE have been acquired over the last ten years from various sources, both wild and cultivated. A. tapete will grow quite readily from seed, the prime requirement being that the seed is fresh. All androsaces should be sown as soon as possible after collection. A normal, well-drained seed compost with added fine grit is suitable and, following germination, the seedlings should be pricked out when still small and with a simple root system.

The plants require very porous, free-draining compost. While they dislike drying out, they will perish if subjected to water-logging and so a lot of grit must be incorporated into the mix. At RBGE we use one part John Innes No. 2 to two parts grit. However, some humus in the form of leaf-mound or peat (as a last resort) is added.

Seed has never been collected from cultivated specimens. Indeed, in the 25 years or so that A. tapete has been grown in this country it has rarely flowered even though it is extremely floriferous in the wild. Cuttings, therefore, are taken to increase stock. These root readily and are taken in June/July. Single leaf-rosettes of new, mature growth are removed from the perimeter of the cushions, dead material is removed and the cuttings inserted into moist sand. With bottom heat of $15^{\circ} \mathrm{C}$, rooting occurs in four to eight weeks.

Both seedlings and cuttings are potted up into plastic pots for their first year and thereafter are moved into clays. The clay pots allow for increased water and air movement between the compost and the plunge. This is vital for the plants' wellbeing, particularly during the colder months. A top dressing of grit or stone shards round the neck of the plant is also important. This $1 \mathrm{~cm}$ deep layer allows air to circulate under the cushion but, more importantly, keeps the vulnerable neck of the plant away from the moist compost.

Androsaces prefer high light levels yet cool growing conditions. To this end we plunge $A$. tapete in a cool north-facing frame over the summer months to give them the benefit of the cooler, fresher conditions. This also lessens the incidence of red spider infestation to which they are prone when grown under glass. They are misted lightly in hot conditions and are given a supplementary liquid feed monthly during the growing season using a product such as Miracle Gro (15:30:15) or Phostrogen $(14: 10: 27)$. The plants are overwintered under glass and repotted in spring if necessary.

\section{APHNE CNEORUM VAR. PYGMAEA. THYMELAEACEAE}

The genus Daphne includes a number of quite delightful, usually fragrant, dwarf shrubby plants for the alpine garden. Daphne cneorum, the garland flower, has a 
wide geographical distribution ranging from Spain eastwards to the Ukraine. It is very variable, producing a range of attractive cultivars and naturally occurring varieties for the rock garden.

Daphne cneorum var. pygmaea is its most diminutive form. It is a highly desirable slow-growing, ground-hugging, evergreen shrub with fragrant pink or occasionally white flowers. The flowers are displayed in tight terminal clusters and, as in all daphnes, are composed of a coloured calyx which forms a slender tube ending in four pointed lobes, giving the flowers a 'starry' appearance. Stems are woody and the evergreen leaves narrowly oblong. In comparison to Daphne cneorum, which can grow to a height of $30 \mathrm{~cm}$ by $100 \mathrm{~cm}$ across in 10 years, D.cneorum var. pygmaea will reach only $2 \mathrm{~cm}$ in height with a spread of $30 \mathrm{~cm}$.

D. cneorum var. pygmaea is found in similar localities to D. cneorum - the Pyrenees, French Alps, Swiss Jura and Venetian Alps. It was first collected in 1930 in the Venetian Alps but was very seldom seen in cultivation until about 20 years ago, when a batch of seed collected in the Pyrenees produced six plants which were subsequently dispersed to other collections. It has been slowly propagated and can now be seen on the show bench and occasionally in nursery lists. As with other rarities, the fact that no seed is produced in cultivation contributes to its scarcity. Vegetative propagation is difficult primarily because the plants are so small and slowgrowing that insufficient propagation material is produced.

The plants currently growing in RBGE came from seed collected in the French Alps in 1996 and have slightly narrower leaves than the Pyrenean form. Daphne seed is known to be slow in germinating and can take six or more months to emerge. Generally only about $15 \%$ of daphne seeds germinate in the spring after an autumn sowing. Seed is best sown fresh and when the fruit is fully ripe. At RBGE seeds are sown in pans of a general gritty seed compost (two parts John Innes seed to one part fine grit) and pots are exposed to a winter chilling in a cold frame. The seedlings are pricked off when large enough to handle, preferably at the start of the growing season. Seed pots are then returned to the frame to allow any ungerminated seeds to germinate.

Once large enough, seedlings are potted up into plastic pots in an open, welldrained yet moisture-retentive compost (one part John Innes No 2 to one part fine grit and one part fine CAMBARK). They are given supplementary feed during the growing season and are not allowed to dry out.

Cuttings can be taken from mature plants in late June after flowering. The base of tip cuttings are dipped in rooting hormone (with incorporated fungicide) and inserted into a tray of rooting medium composed of a 50:50 mix of sharp sand and riddled peat. Bottom heat of $15^{\circ} \mathrm{C}$ is used and has been found to be particularly useful over winter if the cuttings are slow to root. Care has to be taken to ensure that the cuttings do not dry out, and misting and shading on hot and/or sunny days are advisable. The cuttings are best left to establish healthy, strong root systems before potting on. They are vulnerable at this stage and need to be weaned carefully.

Grafting and layering are also possibilities for increasing stocks. The diminutive 
stature of the plant, however, leads to technical difficulties and, in the case of grafting, the fact that the stock would be more vigorous might alter the plants' growth rate and form. Layering is an option that would take advantage of the plant's prostrate form; wounding and pegging down a small shoot in late summer might work although this has not been tried at RBGE in recent years.

Young plants are kept in a frost-free glasshouse over winter and are moved out and plunged in a north-facing cold frame during the summer months. This keeps them cooler and, with occasional misting during hot spells, helps to keep plants free from red spider mite. Daphnes do not seem to suffer from any other pest or disease, apart from the occasional foraging snail which can wreak havoc on such small specimens.

Planted-out specimens cope well with the rigours and unpredictability of our Scottish weather. They perform well in an open sunny position with good drainage and a deep, cool root run which appears to be vital to the plant's wellbeing. A pH on the alkaline side of neutral is preferred and, once planted, established specimens should not be moved unnecessarily.

\section{HELICHRYSUM MONTANUM. COMPOSITAE}

The genus Helichrysum is large, encompassing about 500 species of annuals, perennials, sub-shrubs and trees. They are found throughout the world but particularly in the warmer climes of Africa, southern Europe, south-west Asia, southern India and Australia. Plants vary greatly in shape and form but can be recognised by their flowers - they invariably lack the ray florets of the typical composite and instead have dry, papery bracts which are sometimes coloured and resemble petals, hence their common name 'everlastings'.

Several of the smaller, hardier species are well known in cultivation with their white or silver foliage which is often woolly. They make attractive additions to the rock garden and alpine house. Good examples include Helichrysum bellidioides, a prostrate carpet-growing species from New Zealand, $H$. frigidum, a diminutive finefoliaged silver species from Corsica and $H$. milfordiae, a white, woolly mat-forming species from South Africa. H. montanum is also a South African species. It is interesting to note that, of the 500 species found worldwide, South Africa alone has 245 species and that many from higher elevations are suitable for cultivation in our climate.

H. montanum is a mat-forming, low-growing shrub growing to a height of $10-30 \mathrm{~cm}$ with a spread of one metre or more. Its white, woolly leaves are oblong and clasp the long slender stems in alternate pairs, giving the appearance of rosettes when viewed from above. It is almost rampant under favourable conditions and is a good choice for tumbling down a bank or spilling over a wall.

In the wild it is found growing in thick mats on cliff faces, steep mountain slopes and rocky gullies, often alongside Euphorbia clavarioides, a cushion spurge. It grows at an elevation of around $2,500 \mathrm{~m}$ in the high mountains of Natal, Lesotho and the 
east central Cape. It produces its yellow flowers in the wild between January and April.

The plants currently growing at RBGE were grown from seed collected by the Lesotho-Edinburgh-Gothenburg Expedition (LEG) in 1997. So far these plants have not flowered and it is not known if they produce viable seed in this country. However, new plants can be propagated easily from stem cuttings taken from mid-summer onwards. Branchlets or stem tips $(2.5-5 \mathrm{~cm}$ long) are prepared by cutting away the lower leaves and inserting the cuttings into damp sand or pumice. Rooting hormone is not required and, with bottom heat, the cuttings root quickly. Once rooted they are potted into plastic pots in a gritty compost mix.

As they do not make satisfactory pot specimens, all newly propagated plants are planted out in the rock garden or alpine walls. In general they require well-drained soil in an open sunny situation. At present plants are growing satisfactorily both on a raised wall and sunny scree. They cope with the vagaries of our Scottish weather and do not require winter protection. Pests and diseases do not present a problem.

\section{LILIUM SOULIEI. LILIACEAE}

Lilium souliei, an unusual and rare lily, was named in honour of the French missionary Jean Soulié who collected it in China in the late 1800s. For a long time it was classified under the genus Nomocharis. It is a small lily, in the wild reaching a maximum height of $25 \mathrm{~cm}$. It usually has a solitary, bell-shaped flower, maroonpurple in colour with a glossy finish. It is scented and the flower lies in a horizontal position, at right angles to the stem, a characteristic distinguishing it from its close relative, Lilium nanum. Leaves are alternate, lanceolate and of a dark green colouration.

Native to western China, south east Tibet and Assam, L. souliei was first introduced into cultivation in 1925 and was collected frequently by George Forrest in south east Tibet and Yunnan. However, it did not survive in cultivation and it was not until the 1980s, when plant collectors were permitted to enter China once again, that re-introduction could occur. In 1986 a joint expedition to Yunnan between RBG Edinburgh, RBG Kew and Kunming Institute of Botany in China resulted in the reintroduction of both $L$. souliei and $L$. lophophorum. Subsequent expeditions (Cox 1992, KEG - the Kunming-Edinburgh-Gothenberg Expedition 1993, KGB - the Kunming-Gothenberg Botanic Expedition 1993, and ACE - the Alpine Garden Society Expedition to China 1994) have brought back more material for cultivation. The plant currently growing at Edinburgh was collected as seed by the ACE expedition of 1994 .

The seed is sown in autumn to give it a winter chilling. The flat seeds are sown thinly on the surface of pots of well-drained compost (three parts John Innes seed compost to one part fine grit), covered with a fine sieving of compost and topped with a $5 \mathrm{~mm}$ layer of fine grit. The grit is important as it holds the seed in place and also stops it washing out. The pots are then placed in a cold frame and watered 
lightly. On germination the seedlings are left undisturbed and grown on for as long as possible. They are fed fortnightly while in active growth with a half-strength liquid feed. This, along with normal watering, is reduced when the leaves start to die back. At this stage it is important not to let the pots dry out completely as the bulblets have little substance to cope with drought. During the following year, depending on how vigorously the seedlings have grown, the entire contents of the seed pot can be potted up into a larger pot causing minimum disturbance to the root, and grown on. When they are more mature, they can be cultivated in baskets in a seed frame.

The bulbs show little natural increase by offsets and bulb scaling from the mature bulbs is a possibility for increasing stocks of this rare bulb. The mature bulb is not large, so only one or two of the lanceloate scales could be removed at any one time.

At RBGE mature bulbs are planted deeply in a well-drained, humus-rich compost in clay pots and plunged in a shaded sand frame. They are kept cool and moist throughout the growing season. Pests and diseases do not present a problem apart from the occasional marauding slug or snail. Our intention is to plant this lily out in the peat garden through small rhododendrons, which would give it the cool and damp conditions it requires.

\section{Primula Dryadifolia. Primulaceae}

Primula dryadifolia is an unusual and attractive member of the Primula family. It takes its specific name from its remarkable similarity to the mountain avens, Dryas octopetala, in both habit and foliage. It is an evergreen perennial, in the wild forming large mats of woody rhizomes with leathery, often shiny oak-leaf shaped leaves with turned-down margins which are mealy underneath. The calyx is bell-shaped and the flowers, borne in heads of 1 to 5 on a $10 \mathrm{~cm}$ stalk, are rose or magenta in colouration, often with a yellowish or darker eye. It flowers in June in the wild shortly before the monsoon.

It is a high alpine plant, found at elevations between $3,000-5,000 \mathrm{~m}$, often in crevices or rock ledges but also in screes and stony pastures. Its distribution is wide, ranging from east Bhutan, through south east Tibet, western Yunnan and Burma to Sichuan.

P. dryadifolia was first discovered by Jean Delavay in 1883 in Yunnan and was introduced into cultivation by George Forrest in the early 1900s. However, it proved to be short-lived and repeated introductions failed. Some post-war Ludlow and Sherriff collections are known to have survived for 20 years in particular Scottish gardens, but by the mid-1970s the species was thought to be lost to cultivation. However, in 1987 it was reintroduced from the Yulong Xue Shan in Yunnan and further expeditions to China over the past 10 years have brought in more seed. As a result, a number of accessions are grown at RBGE and at present we have both mature and young plants growing from seed collected by the 1994 ACE expedition.

As cuttings of $P$. dryadifolia show a reluctance to root, plants are generally raised from seed. Seed is sown in our general seed compost (two parts John Innes seed 
compost to one part fine grit) with some fine riddled peat added. It is sown thinly in plastic pots and topped with a layer of fine grit. The pots are bottom-watered and then placed outside in a cold frame until germination takes place. Ideally primula seed should be sown as soon as it is ripe, for quicker germination. However, if seed is stored for any time it assumes a secondary dormancy which requires a winter's chilling to break. If this is the case then seed should germinate the following spring.

Once the seedlings have developed two true leaves they are pricked out and potted up singly into small clay pots in a gritty compost with some humus added, preferably leaf mould. They are top-dressed with grit and plunged in moist sand in a cool frame. The plants are kept moist during the growing season and are not allowed to dry out at any time. Plants are fed with a half-strength general liquid feed throughout the summer and are repotted as required while in active growth. A good indicator for this is when roots grow through the drainage holes.

The leathery leaves and woody rhizomes suggest that the species might tolerate high temperatures, but this is not the case. Plants become stressed and die under these conditions. To avoid this a gentle misting during hot conditions helps keep the plants cool as does keeping the sand plunge moist. During winter plants are kept just moist and young plants are moved into a frost-free glasshouse to give them extra protection.

Pests and diseases do not appear to present such a great problem to $P$. dryadifolia in comparison to other primulas, for instance those in the Petiolares section. The leathery foliage does not seem to attract either aphids or botrytis, the scourge of many Himalayan primulas, however we remain vigilant to the depredations of the vine-weevil larvae.

\section{Stellera chamaejasme. Thymelaeaceae}

Stellera chamaejasme is a highly desirable alpine plant. It is a herbaceous perennial, hardy and potentially long-lived, with an attractive hummock-like form when mature. The plant has a woody rootstock which in time builds into a substantial crown from which numerous stems sprout. The stems are unbranched, slender and about $30-50 \mathrm{~cm}$ high. Leaves are greyish green and alternate with a shape ranging from narrow lanceolate to ovate. Each stem is topped with a rounded head of up to 50 scented tubular flowers which are white (S. chamaejasme var. chamaejasme) or yellow (S. chamaejasme var. chrysantha).

S. chamaejasme has a wide geographical range stretching from the Altai Mountains in Russia through Mongolia, northern China, Tibet and into the western Himalayas. It is usually found on dry mountain slopes and grazed meadows at an altitude of $1,800-3,900 \mathrm{~m}$ and, like most members of Thymelaeaceae, it is poisonous and resistant to grazing.

S. chamaejasme has been a rarity in cultivation principally because it is difficult to propagate. It cannot be divided because it has a single woody tap root, cuttings cannot be taken and plants seed rarely in this country. For many years there were 
only three gardens in Scotland holding plants of a 1950s Donald Lowndes collection from the Marsyandi Valley in central Nepal. For 50 years the Rock Garden at RBGE was graced by a plant which in size rivalled specimens seen in the wild.

Seed collecting expeditions in the 1980s brought seed back from Nepal and, as a result, plants started to trickle into circulation. Further expeditions to both Nepal and China in the 1990s returned with more seed and now plants of both the Nepalese pink-budded form (S. chamaejasme var. chamaejasme) and the Chinese yellow form (S. chamaejasme var. chrysantha) can be seen in alpine plant collections.

To date seed is the only viable method of propagation. Seed is thought to have a short viability and as such should be sown as soon as possible after collection. Seed that has been stored should be soaked in water for 24 hours prior to sowing. Here at $\mathrm{RBGE}$ the plump rice grain sized seeds are sown into pans filled with a gritty seed compost (three parts John Innes seed to one part fine grit) and topped with a layer of fine grit. These are placed outside in a cold frame until germination takes place. This can take up to four years.

Once germinated, the seedlings are grown on and are pricked out when large enough to handle but before the tap root becomes too long. The ideal time would be in spring before growth starts. As some seed displays delayed germination, care should be taken when removing the seedlings and the seed pans returned to the cold frame for future germination.

Seedlings and young plants are grown on in gritty humus-rich compost in clay 'long-toms' to accommodate the long tap root. They are plunged in a sand-filled frame open to the elements between the months of April and September. Plants are slow to develop but by three or four years they are of a size suitable for planting out. Restricting them to pots after this age is detrimental and a sunny raised bed with sharp drainage and an open aspect appears to be the most satisfactory position for them. Plants increase slowly and it may take five or more years before any flowers are produced.

Once planted, stelleras should never be moved. In common with other members of the family they dislike transplanting and respond by dying. Plants come into growth late in the season, often in April and thus miss any late frosts. In winter we cover them with panes of glass to keep off winter wet. Mature specimens probably would not require this winter protection.

Pests and diseases tend not to present a problem, apart from slugs or snails grazing on newly emerging shoots. 